Adrian Gellel

University of Malta

\title{
Adaptive Religious Education at the Service of Inventiveness: A scientific way of being creative and effective in Religious Education
}

\begin{abstract}
Student uniqueness demands that the teacher/catechist is inventive not only in the learning methods and teaching techniques employed but also in the way content is structured. Only in this way can the teacher ascertain that his/her students' requirements are met and, consequently, student learning facilitated. However, teachers' creativity should not mean haphazard choice of methods and techniques. Teaching is both an art and a science. The limitless nature of creativity should be used judiciously and made to bear fruit through the application of knowledge of educational psychology and instructional design. By using Adaptive Religious Education, the teacher may be guided to use different techniques in a methodical manner in order to ensure and enhance student learning. In particular, the systematic use of different symbol systems can help teachers to improve student learning. The paper will put forward a number of principles and practical suggestions that may guide teachers in planning R.E. lessons.
\end{abstract}

\section{Keywords}

Adaptive Religious Education, Symbol System, Teaching Methods.

\section{Introduction}

There is no quibbling about the fact that Religious Education is one of the oldest scholastic subjects, tracing its origins back to Antiquity and that it found its place at the centre of the curriculum all through medieval and modern 
periods ${ }^{1}$. Similarly, it is also indisputable that the Science of Catechetics as an academic discipline, understood mainly as the teaching of religion to children and infants, was already present in universities as early as $1774^{2}$. Yet, a survey of the papers in educational psychology and instructional design journals reveals that normally the scholastic subjects under the spotlight are those concerning mathematics, languages and the sciences. Rarely does one find research papers dealing specifically with the education of beliefs, attitudes and values, let alone articles on Religious Education. Similarly, it is unusual for academics researching in the field of Religious Education to use the findings of the educational sciences in the construction of methodological and pedagogical theory.

The sidelining of Religion from the classroom and from educational academic discourse may be attributed to a deeper malaise than simply the secularisation process. So, while on the one hand education and religious associations advocate for a holistic education that incorporates religious and spiritual education, on the other hand, as Sewall rightly points out, religious and secular fundamentalists set the frame of public discourse even within education ${ }^{3}$. What is at stake is precisely the identity of Religious Education.

From its very inception as an academic discipline, the identity of Religious Education oscillated between Theology and the Sciences of Education. A clear example of the debate on the theological or pedagogical nature of Religious Education and Catechesis is evident in the Austrian reform of Theology of the late eighteenth century ${ }^{4}$. At first, Catechetics and the Religious Instruction of infants were understood to be an integral and principal component of Practical Theology. However, some ten years later it was seen as an autonomous discipline to be taught by a pedagogue. This alternation between theology and pedagogy, continued all throughout the nineteenth century. It seems however clear that the identity of Religious Education lies in its interdisciplinary vocation. On the one hand, due to its religious nature, Religious Education is called to draw from the wisdom, the reflections and theology constructed by the believing community. However, being a pedagogical discipline, Religious Education is also called to

${ }^{1}$ See C. Kapitzke, \& P. Graham, Curriculum and Religion, in: P. Peterson, E. Baker, \& B. McGaw (eds.), International Encyclopedia of Education, Amsterdam 2010, Elsevier Science, pp. 273-276.

${ }^{2}$ See P. Braido, Lineamenti di storia della catechesi e dei catechism. Dal «tempo delle riforme» all'eta degli imperialismi (1450-1870), Leimann (Torino) 1991, Publishing House Elle Di Ci.

${ }^{3}$ See G.T. Sewall, Religion in the Classroom: What the textbook tells us, American Textbook Council 1991. Available online http://historytextbooks.org/religion.pdf.

${ }^{4}$ See P. Braido, Lineamenti di storia della catechesi e dei catechism. Dal «tempo delle riforme» all'eta degli imperialismi (1450-1870), Leimann (Torino) 1991, Publishing House Elle Di Ci. 
take note of and follow the advancements made in the Educational Sciences, particularly Educational Psychology and Instructional Design. Just as much as Religious Education would be unthinkable without theological input, so it would be inconceivable without the input of the Educational Sciences. The separation of the two would only lead to either isolation or lack of direction and purpose.

This emphasis on the identity of Religious Education prior to any discourse on methodological principles that may enhance teaching and learning is important. Grounding Religious Education in the current theories and practices of Theology and the Educational Sciences enhances the credibility of the subject and lessens the concrete prospect of having a ghettoised scholastic discipline. Furthermore, as Lee argues, the approach by which Religious Education is taught is to be understood as important content in itself ${ }^{5}$. Consequently, the didactic tools and methods used in classrooms are not only means to present content but are themselves part of the content.

\section{Introducing the A.R.E. Method}

Research on Adaptive Religious Education stemmed from the real need and call to meet individual differences in the classroom ${ }^{6}$, and from the belief that it is possible to conduct a dialogue amongst the disciplines of Divine Pedagogy and Religious Education as well as Educational Psychology and Instructional Design. The more I delved into these areas, the more I discovered not only the richness of each individual discipline, but above all I was surprised by the depth and richness that already existed in the Tradition and writings of the believing community on this area of study.

Slavin reported how through the past two millennia, various Christian philosophers and theologians reflected on the reality of individual differences

${ }^{5}$ See M.J. Lee, Facilitating Growth in Faith Through Religious Instruction, in: M.J. Lee (ed.), Handbook of Faith, Birmingham, Alabama, 1990, Publishing House REP, p. 266.

${ }^{6}$ For instance see Congregazione per il Clero, Direttorio Generale per la Catechesi, Città del Vaticano 1997, Publisher Libreria Editrice Vaticana, article 170; see Paul VI, Apostolic Exhortation Evangelii Nuntiandi (8 December 1975) http://www.vatican.va/holy_father/paul_vi/ apost_ exhortations/index.htm, article 44; see Sacra Congregazione Del Clero, Direttorio Catechistico Generale (11 Aprile 1971), Leumann (Torino) 1986, Publishing House Elle Di Ci, article 34; see Second Vatican Council, Christus Dominus (28 Octoberr 1965), in: A. Flannery (ed.), Vatican Council II. The conciliar and post conciliar documents, Bombay 1988, Publishing house St Paul Publications, article 14. 
and its effects on education ${ }^{7}$. Furthermore, there are also indications how individuals tried to respond to these differences. For instance, Braido reported how the pedagogue and bishop Milde (1777-1853) adopted and encouraged a catechetical method that took into consideration the recipient's age, cognitive ability and cultural background. Similarly in 1824, Weinkopf, a teacher at St. Anne's public school in Vienna, published two books, one on scientific catechesis and the other on the teaching of catechesis in schools ${ }^{8}$. In his work it is evident that he was concerned, amongst others, with teaching students according to their comprehension abilities.

The tradition of the Christian community is able to set the right framework and point the way forward in dealing with individual differences in the classroom. So, while research in differentiation and adaptation is normally rooted in a philosophy that believes in equity, specifically understood as the guaranteeing for every individual the opportunity to run his/her strongest race in society, a Christian anthropology insists on seeking to optimise every student's potential. The latter may only be understood in the will of the Christian community to promote the human person and to make the human person more human. Furthermore, through its tradition and theology Christianity may also contribute by pointing to the need of taking a holistic stance to research and to the understanding of the human person. Cronbach and Snow admitted that a major problem with most research in the area of the interaction between Aptitude and Treatment during the sixties and seventies was precisely the fact that researchers chose only one or two human aptitudes, normally intelligence and scholastic attainment, with the consequence that they ignored the complexity of human uniqueness ${ }^{9}$. Once again, a Christian understanding of the human person points not only to the uniqueness and unrepeatable nature of every individual but also to the relational aspect of the human person. The notion of person in Christianity reflects individuality and at the same time, openness to others and the Other. It is precisely in this relationship and communion that the person is continuously constituted. Furthermore, in addressing the concept of "human person" through Christian tradition one acknowledges wholeness rather than fragmentation.

\footnotetext{
${ }^{7}$ See R. J. Slavin, The Philosophical Basis for Individual Difference According to Saint Thomas Aquinas, Washington D.C. 1936, Publishing House Catholic University of America, p. 3.

${ }^{8}$ See P. Braido, Lineamenti di storia della catechesi e dei catechism. Dal «tempo delle riforme» all'eta degli imperialismi (1450-1870), Leimann (Torino) 1991, Publishing House Elle Di Ci. p. 332.

${ }^{9}$ L.J. Cronbach, and R.E. Snow, Aptitudes and Instructional Methods. A Handbook for Research on Interactions, New York 1977, Publishing House Irvington, p. 493.
} 
The dialogue between disciplines resulted in the development of four major principles that underpin the theory and method of Adaptive Religious Education (A.R.E) ${ }^{10}$. These principles emanate from the study of the biblical community's experience of the adaptive Pedagogy of God and are in some way congruent with the possibilities offered by present research in education and psychology, namely

i. respect for the human person,

ii. tension and complimentarity between community and individual,

iii. use of differentiated methods, and

iv. progressive formation of the self.

The specific contribution of these four principles lies in setting the boundaries and the supporting structure for the design of textbooks and learning materials. In particular, principles (i) and (ii) point to the need of taking into consideration the complexities of uniqueness and indicate that in order for learning to be meaningful it needs to occur in the context of a learning community. Principle (iii) builds on the concept that effective teachings needs the creation of an environment that supports a match between the learning aptitudes of students and the didactic material. Finally, principle (iv) emphasises that education is a journey where the individual and the community are the main protagonists as well as agents.

One of the main arguments for A.R.E. is that Religious Education should cater for individuals and not merely present didactic material suitable for the masses. Even in the most homogeneous class, which in normal scholastic terms would entail grouping students according to their ability and subject choices, there would be a variety of aptitudes. Human uniqueness implies that no one student is identical to any other student that the teacher will encounter throughout his/ her teaching career. This requires considerable investment in preparing lessons and didactic material that guarantees learning. However, even though creativity implies originality and working outside rigid margins, this does not mean that the A.R.E. method is diametrically opposed to a scientific method. Indeed the opposite is true.

Teaching is both an art and a science. While it is true that uniqueness requires inventiveness, it is also true that in-depth knowledge of students' aptitudes, how these interact with each other and their effect on learning is needed since the formulation of didactic techniques needs to be based on scientific know how. Unfortunately, the situation lamented upon by Cronbach remains. More than

${ }^{10}$ See A.M. Gellel, Adapting Religious Education to Individual Requirements. A Means of Being Faithful to the Pedagogy of God in the Classroom, Malta 2007, Publishing House Foundation for Theological Studies. 
sixty years ago, during his presidential address to the American Psychological Association, Cronbach complained that research was limited by the division that exists between experimental psychology which is interested in understanding the effects on different treatments, and correlational psychology which is interested in classifying different individuals. He insisted that a new kind of research is needed, a research which unites the study of variance among individuals and the variance among treatments. He labelled this research approach AptitudeTreatment Interaction (ATI) ${ }^{11}$. Alas, this holistic vision of research and practice in education did not materialise. Researchers continue either working hard on the discovery of individual difference constructs with adequate measurements or trying to find the most effective pedagogy to implement in the classroom. On the other, most teachers tend to prepare lessons basing mainly on intuition and on experience gained.

\section{Definitional Issues}

The promise of a method that reduces the gap between high and low achievers and that responds better to individual requirements is no chimera. The practicability and validity of A.R.E. was tested by the author through an empirical research involving some 1200 13-year-old students. Overall, the results indicated that, students administered the A.R.E. treatment significantly outperformed students who underwent the typical R.E. treatment. More importantly, results indicate that that the A.R.E method was not only successful in helping better retention but it was also successful in reducing the gap between normally high and low achievers. Thus A.R.E. was more capable of meeting individual differences in the classroom. A better exposition of the theory and method of A.R.E has been discussed discussed elsewhere ${ }^{12}$. For the purpose of this paper I shall focus on the application of the third principle of A.R.E, that is the use of differentiated methods.

${ }^{11}$ See L.J. Cronbach, L. J. The Two Disciplines of Scientific Psychology, “American Psychologist” 12 (1957) Nr. 11. p. 681.

${ }^{12}$ See A. M. Gellel, Adapting Religious Education to Individual Requirements. A Means of Being Faithful to the Pedagogy of God in the Classroom, Malta 2007, Publishing House Foundation for Theological Studies; A.M. Gellel, Adapting to the Requirements of the Individual in the R.E. Classroom, in: M. de Souza, K. Engebretson, G. Durka, R. Jackson, \& A. McGrady (eds.), International Handbook of the Religious, Spiritual and Moral Dimensions of Education, Netherlands 2006, Publishing House Springer, p. 1093-1109. 
Throughout the eighties and nineties, Richard Snow, a student and eventually a colleague of Cronbach, worked on a suitable language that could help overcome the obstacles of fragmentation and individual uniqueness. Working on the theories of Simon, Gibson and Cronbach, Snow defined his theory of learning aptitude ${ }^{13}$. Snow understood that the person has a number of propensities, in the same manner that the situation affords affordances. For Snow, propensities are what a person accumulates and brings to a given situation; namely one's biological characteristics and one's accumulated experiences, and the continuous interaction between the former and the latter that creates new propensities. On the other hand, affordances are what the situation affords, that is, the possibilities that the situation offers. Snow defines aptitude in a wider way than it is normally understood. For him an aptitude lies outside the person. It occurs when there is attunement between the propensities of the individual and the affordances of the situation. An example from the inanimate world might help us understand the concept. An oblong object has the propensity to stand straight, on the other hand, a horizontal plane offers the affordance of allowing an object to stand on it. When putting the oblong object on the horizontal plane we have attunement, that is, a perfect match between the oblong's propensity and the horizontal plane's affordance. If the plane were slanting, than the oblong's propensity is of no use since no attunement is possible.

In the same manner that the person has an array of propensities, any situation presents a range of stimulus components that may or may not be new to the student's learning history. These stimulus components may represent a challenge, a demand or present opportunities. However, they may also replace the need for certain propensities on the student's part. It should be pointed out that just as the individual is transformed by the situation, the individual also contributes to the construction of the situation s/he is in. Furthermore, the propensities of a group of persons act as affordances for each other. Nonetheless, whilst implying it, Snow never really put emphasis on the social dimension of the situation.

A major implication of this way of comprehending aptitude is that it allows for a holistic understanding. Aptitude does not lie within the person but in the interaction between the person and the situation. One immediately realises that a person may benefit from the affordances of a particular situation but not benefit from similar affordances in a different situation. For Snow, this implies that

${ }^{13}$ See R.E. Snow, The Concept of Aptitude, in: R. E. Snow \& D. E. Wiley (eds.), Improving Inquiry in Social Sciences: A volume in honour of Lee J. Cronbach, Hillsdale, New Jersey 1991, Publishing House Lawrence Erlbaum Associates, p. 249-284. 
in education particular instructional treatments may benefit some students by offering affordances that can be attuned to their propensities ${ }^{14}$.

Beside working on a definition of aptitude, Snow also worked on how humans interact with knowledge and information. In one of his last articles, Snow suggests the idea that students come to the classroom with different symbol systems, for instance, language, culture and visual as well as verbal luggage ${ }^{15}$. According to Snow, humans have developed these symbols throughout history according to their own abilities. In turn, these systems have, over different generations, shaped the profile of ability development. He notes that, presumably because of both biological and environmental reasons, not all develop proficiencies in all symbol systems. A clear example of this statement is the different measures needed to measure the same construct of intelligence in people pertaining to different races and cultures.

Symbol systems and abilities overlap in many subtle and important ways. For instance, verbal intelligence and verbal style have a constant affinity with the symbols of language expressed in writing, reading, listening to a language, spelling, knowledge of meaning etc. Each of these expressions can be broken down into different components. For example, the act of writing includes such skills as repertoire of language, construction of situations, and retrieving meaning.

Teachers need to be sensitive to these symbol systems operated by students in order to adjust instruction accordingly. Snow believed that teachers' sensitivity to individual differences and their ability to build a list of symbol systems, including their components, is key to judge student strengths and weaknesses. He was of the opinion that teachers, as professionals, ought to be able to pass on the spot judgements and remedy weaknesses through the approach adopted during instruction and through the development of students' capabilities.

\section{The differentiated method}

Consequently, in the context of A.R.E., differentiating learning means manipulating as much as possible a given situation in order to provide as much affordances as possible so that attunement with the student's propensities is possible. The learning situation includes the physical learning environment, the

${ }^{14}$ See R.E. Snow, Aptitude Theory: Yesterday, Today, and Tomorrow, "Educational Psychologist" 27 (1992) Nr. 1, p. 8.

${ }^{15}$ See R.E. Snow, Aptitudes and Symbol Systems in Adaptive Classroom Teaching, "Phi Delta Kappan” 78 (1997) Nr. 5, 354-360. 
teacher, the teaching method, the didactic materials and the textbook used, as well as the use of the propensities of the students themselves. Thus, for instance, manipulating a learning situation could mean changing the disposition of benches, controlling the levels of light, using or not using technology, using a textbook that is sensitive to different aptitudes, using different didactic techniques as well as using the prior knowledge and experience of students.

The manipulation of a given learning situation should not occur haphazardly. Ideally, it should be done in the knowledge of the students' propensities. However, a major hurdle is posed by the complexity of human individuality. There is not, as yet, a definitive assessment or group of assessments that allows for a more comprehensive study of the complexity of uniqueness. Guilford has already tried to produce a model that encapsulates different aspects of individual differences in the process of learning. However this model has resulted to be too complex and preliminary data has not been supportive ${ }^{16}$. On the other hand, the aptitude complexes studied by Snow, Corno and Jackson and later by Ackerman seem to yield interesting results ${ }^{17}$. Yet, the teacher, or rather the educational institution, may be able to design a wide enough Student Profile that could give indications against which to plan and design learning. This profile should be able to indicate not only cognitive propensities such as scholastic ability, cognitive style and intelligence but also give indications about students' interests, approaches to learning, prior knowledge and experience.

Moreover, besides creating a generic student profile that allows a better cognisance of student requirements, the teacher should also create a repertoire of teaching techniques and categorise them according to the different symbol systems. In developing the Adaptive Religious Education method, three major Symbol Systems were identified, namely the Verbal, the Visual and the Concrete.

Humans normally perceive and interact with knowledge and information outside themselves through their senses. It is through the senses that we are able to see, listen, touch, taste and smell the outside world. We are continuously bombarded with information which our brain, through the Working Memory Capacity ${ }^{18}$, decides which to take heed of and which to ignore. In the same manner, raw information is processed and communicated through the main representations

${ }^{16}$ See J.P. Guilford, Way Beyond the IQ: Guide to Improving Intelligence and Creativity, New York 1977, Publishing House McGraw-Hill.

${ }^{17}$ See P.L. Ackerman, Aptitude Complexes and Trait Complexes, "Educational Psychologistt" 38 (2003) Nr. 2, p. 85-93; R.E.Snow, L. Corno, and D. Jackson D. III., Individual Differences in Affective and Conative Functions, in: D. C. Berliner \& R. C. Calfee (eds.), Handbook of Educational Psychology, New York 1996, Publishing House MacMillan, p. 243-310.

${ }^{18}$ See A.D. Baddeley, Working Memory, Oxford, U.K. 1996, Publishing House Clarendon. 
of Visuals, Verbals, which include sound, and other concrete expressions, which include touch, smell and taste. In view of this insight it is possible to categorise different teaching techniques according to the three main symbol systems. Table 1 gives an indication of how this may be done.

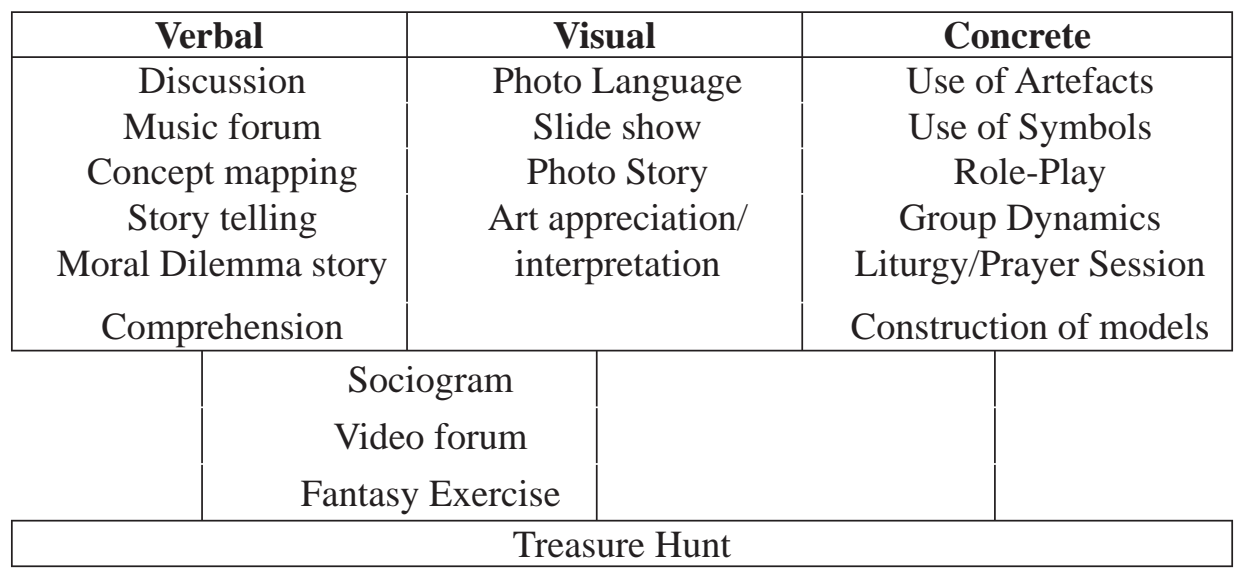

Table 1: Examples of Teaching Techniques by symbol system.

In no way does the table above claim to be complete. Indeed it is only intended as an example and a preliminary tool for teachers to use and continue to update. It should be noted that the didactic techniques mentioned in the table only present a bias towards a particular system symbol and are not exclusive.

One of the most efficient ways of manipulating the learning situation is by ascertaining that students are exposed to different symbol systems, at least through teaching techniques. The capability to use different symbol systems assures the possibility of attunement occurring in all students at some point in time. Differentiation may occur over a period. In this context, the practical principle of differentiated methodology refers to having lesson plans that balance and alternate between the different symbol systems and having didactic material that offers a wide variety of affordances. Thus, in planning their schemes of work, teachers using A.R.E. will purposefully balance among the different symbol systems over the duration of a given unit/chapter. Indeed, it is even possible to plan the lesson plan with short 10 minute learning activities that utilise different symbol systems during the lesson. The deliberate balance in the use of didactic techniques over a period of 6/8 lessons, and possibly during the same lesson, is made in order to 
avoid any bias in favour of one learning approach, thus increasing the possibility of attunement within each lesson delivered in the unit.

A final word of caution is nonetheless needed. Teachers are reminded that the writing of learning outcomes remains central to lesson planning. It is on the bases of learning outcomes that specific learning activities are planned and evaluated. It is then possible to plan various learning activities using different symbol systems, and indeed even different techniques of the same symbol system for the same learning outcome.

\section{Conclusion}

The empirical research on the A.R.E. ${ }^{19}$, indicates that the use of, and the differentiation amongst, symbol systems has been successful in providing an array of affordances for different student propensities. Although the combinations are infinite, detecting symbol systems and understanding the affordances they provide would be a step in the right direction. Consequently, there is need to conduct more empirical research on the interaction between aptitude and situational complexes. Such research is vital since it provides the basis for developing didactic materials and prescriptive guidelines.

Nonetheless, by following the simple principle of differentiation among the three identified symbol systems, teachers can already contribute considerably to meet students' requirements and thus promote meaningful learn during the R.E. class. Using the same techniques, or even an array of four techniques carefully balancing among the three symbol systems defeats the whole purpose of offering as much affordances, and therefore the possibility of attunement. Teachers have to be creative and devise different ways of presenting the same learning objectives by using different symbol systems and also by varying in the didactic techniques used.

19 See A. M. Gellel, Adapting Religious Education to Individual Requirements. A Means of Being Faithful to the Pedagogy of God in the Classroom, Malta 2007, Publishing House Foundation for Theological Studies; A. M. Gellel, Adapting to the Requirements of the individual in the R.E. Classroom, in: M. de Souza, K. Engebretson, G. Durka, R. Jackson, \& A. McGrady (eds.), International Handbook of the Religious, Spiritual and Moral Dimensions of Education, Netherlands 2006, Publishing House Springer, p. 1093-1109. 


\section{Bibliography}

Ackerman P.L., Aptitude complexes and trait complexes, "Educational Psychologist” 38 (2003) Nr. 2, p. 85-93.

Baddeley A.D., Working Memory, Oxford, U.K. 1996, Publishing House Clarendon.

Braido P., Lineamenti di storia della catechesi e dei catechism. Dal «tempo delle riforme» all'eta degli imperialismi (1450-1870), Leimann (Torino) 1991, Publishing House Elle Di Ci.

Cronbach L.J., The two Disciplines of Scientific Psychology, "American Psychologist” 12 (1957) Nr. 11, p. 671-684.

Cronbach L. J. and Snow R.E., Aptitudes and Instructional Methods. A Handbook for Research on Interactions, New York 1977, Publishing House Irvington.

Congregazione per il Clero, Direttorio Generale per la Catechesi, Città del Vaticano 1997, Publishing House Libreria Editrice Vaticana.

Gellel A. M., Adapting Religious Education to Individual Requirements. A Means of Being Faithful to the Pedagogy of God in the Classroom, Malta 2007, Publishing House Foundation for Theological Studies.

Gellel A. M., Adapting to the Requirements of the Individual in the R.E. Classroom, in: M. de Souza, K. Engebretson, G. Durka, R. Jackson, \& A. McGrady (eds.), International Handbook of the Religious, Spiritual and Moral Dimensions of Education, Netherlands: Publishing House Springer, p. 1093-110.

Guilford J. P., Way Beyond the IQ: Guide to Improving Intelligence and Creativity, New York 1977, Publishing House McGraw-Hill.

Kapitzke C. \& Graham P., Curriculum and Religion, in: P. Peterson, E. Baker, \& B. McGaw (eds.), International Encyclopedia of Education Amsterdam 2010, Publishing House Elsevier Science, p. 272-276.

Lee M. J., Facilitating Growth in Faith Through Religious Instruction, in: M.J. Lee (ed.), Handbook of Faith Birmingham, Alabama 1990, Publishing House REP, p. 264-302.

Paul VI, Apostolic Exhortation Evangelii Nuntiandi 1975, http://www.vatican. va/holy_father/paul_vi/apost_exhortations/index.htm.

Sacra Congregazione del Clero Direttorio Catechistico Generale, Città del Vaticano 1971, Publishing House Libreria Editrice Vaticana.

Second Vatican Council, Christus Dominus 1965, http://www.vatican.va/archive/ hist_councils/ii_vatican_council/documents/vat-ii_decree_19651028_ christus-dominus_en.html. 
Sewall G.T., Religion in the Classroom: What the Textbook Tells Us, American Textbook Council 1995, http://historytextbooks.org/religion.pdf.

Slavin R.J., The Philosophical Basis for Individual Difference According to

Saint Thomas Aquinas, Washington D.C. 1936, Publishing House Catholic University of America.

Snow R.E., Aptitudes and Symbol Systems in Adaptive Classroom Teaching, "Phi Delta Kappan” 78 (1997) Nr. 5, p. 354-360.

Snow R.E., Aptitude Theory: Yesterday, Today, and Tomorrow, "Educational Psychologist” 27 (1992) Nr. 1, p. 3-52.

Snow R.E., The concept of Aptitude, in: R.E. Snow \& D.E. Wiley (eds.), Improving Inquiry in Social Sciences: A volume in honour of Lee J. Cronbach, Hillsdale, New Jersey 1991, Publishing House Lawrence Erlbaum Associates, p. 249284.

Snow R.E., Corno L., \& Jackson D., III. Individual Differences in Affective and Conative Functions, in: D. C. Berliner \& R. C. Calfee (eds.), Handbook of Educational Psychology, New York 1996, Publishing House MacMillan, p. 243-310. 